\title{
Veal Calves, an Alternative System to Increase the Profitability of Dairy Sectors. Feasibility Study
}

\author{
Eirin Mariano Antonio ${ }^{1}$, Muro María Gabriela1, Arias Rubén \\ Omar¹, Heguy Bárbara1', Barouille Eliana1, Piro María Soledad ${ }^{1}$
}

${ }^{1}$ Facultad de Ciencias Agrarias y Forestales. Universidad Nacional de La Plata, Calle 60 y 119 s/n. La Plata (CP 1900). Buenos Aires. Argentina

\begin{abstract}
With the purpose of increasing the profitability of milk producers, a pilot study for the production system of veal dairy calves was conducted. This type of rearing is not practiced in our country at present. The study was carried out in the establishment of "cabaña Alicia" dairy farm, located in the district of Magdalena, province of Buenos Aires. 12 Argentinean Holando breed male non-castrated calves were employed for this study, and they were fed on a milk replacer-based liquid diet, to obtain a pale meat as the final product. This kind of meat is characteristic of Europe and also quite widespread throughout this continent. Fortnightly weighting was performed to control the daily body weight gain (DWG). Finally, the calves were slaughtered six months later, with an average DWG $0.73 \mathrm{~kg} /$ day, average BW $181 \mathrm{~kg}$, and beef yield $57.6 \%$; blood iron exams at the end of the cycle resulted in average $7.8 \mathrm{gr} / \mathrm{dl}$, considered within the expected parameters to avoid the occurrence of anemia. Thus, we can conclude that this production proposal, compared to traditional artificial calf rearing, is a convenient opportunity to those producers who can enter the market of this kind of meat, or seek consumption sites in our country.
\end{abstract}

Keywords: Veal Calves, Rearing, System, Dairy

\section{INTRODUCTION}

Milk industry is one of the most important food industries in the country. Primary production in Argentina between 2008 and 2015 reached an average production level of 10,700 million liters, mainly concentrated in Buenos Aires (23\%), Santa Fe (28\%) and Córdoba (28\%) and, in a lesser degree, in Entre Ríos and La Pampa, with around 2 and 1\% respectively. The main dairy production areas, and almost all dairy farms and milk industries are located in these provinces (Bisang, Gutman y Cesa, 2003).

The profitability of dairy farm exploitation in the country has been compromised in the last years. This has caused the cessation of the activity in some cases, and the reorientation of the activity in others. Taking into account this situation and, in the need to offer feasible solutions to the exploitation, meat production could be proposed as an alternative to milk production. Also, this proposal can respond to the growing demand of the European market of young calf meat reared in natural conditions.

This production system involves the artificial rearing of calves, which consists of prematurely separating the calves from their mothers, so that cows can be milked. Such artificial rearing system may be employed collectively or individually, using pegs or in cages. In all cases, calves are separated from their mothers after the calostrum consumption within the first 12 hours of life (12 hours approximately). This is the first food supplied to the calf, and it contains immunologic value. In ruminants, there is no placental immunity during the fetal developmental stage, because the placenta avoids the passage of antibodies from the mother's blood to the fetus (Hazard, 1993).

It is important to point out that general rearing involves female cows, which are necessary for the replacement of productive animals. Males are sold to low prices before or after the rearing period because their reproductive use is limited. A very small number of bulls is needed for natural reproduction and, also, the use of artificial insemination is widely adopted. In addition, being a milk breed, they are undervalued as meat producers. For calves to finish their fattening periods takes a long time, which means a higher cost and this makes them unprofitable.

In Argentina, approximately around 2,000,000 Argentinean Holando calves are born every year, of which $50 \%$ are male and $50 \%$ female. Artificial

This article is published under the terms of the Creative Commons Attribution License 4.0

Author(s) retain the copyright of this article. Publication rights with Alkhaer Publications.

Published at: http://www.ijsciences.com/pub/issue/2017-08/

DOI: 10.18483/ijSci.1421; Online ISSN: 2305-3925; Print ISSN: 2410-4477 
rearing implies an important cost in our country's milk production systems, and that may affect their profitability, since chances of selling milk breed calves for fattening are quite limited. For these reasons, producers offer calves to the market at low prices, and in some cases, they slaughter them after birth.

An alternative for this would be the rearing of veal dairy calves, to create a differential final product of high added value. As this product is not habitually commercialized in our country, it would be necessary to conduct a market research, and to explore the possibility of exportation. Veal calves are a kind of artificial rearing characterized by having a dairy replacer-based liquid diet. This kind of food allows for a product of differential features, compared to the ones that already exist in the market at present (Vieira et. al., 2004).

The peculiarity of the final product is the pale white color of the meat and its particular flavor, very much appreciated in certain markets. The high nutritive value of dairy food allows for a fast growth and an appropriate fat covering. This peculiar color is the result of an iron and fiber deficiency. Iron carries oxygen in hemoglobin and acts on myoglobin (pigment which colors the meat red) provoking this color, because of a lesser amount than usual (Bremner \& Dalgarno, 1972).

To accomplish this result, it is necessary to maintain a certain level of anemia, so that it does not alter weight gains, but that it does not change the color of the meat either. Such levels range around 7 and 10 $\mathrm{g} / \mathrm{dl}$. Fiber deficiency in the diet prevents the calf to develop the rumen as normal, being the rennet the one mainly digesting the dairy diet. As a result, calves behave as monogastric (Lumsden et al., 1980).

The consumption of this product at a global level is to be found mainly in the member countries of the
European Union, including France, Germany, Italy, United Kingdom and Spain. Within the American continent, the United States consumes 0.2 kilograms per capita, per year. The primary commercialized meat cuts are: leg, tenderloin, short loin, rib, shoulder, chuck and brisket. These are used for the elaboration of high cuisine dishes of an elevated value.

For the exportation of this kind of 'differential' meat, the current regulations affect the price for an exportation right of $5 \%$ and there are not reimbursements of any kind. Since they are considered as 'high quality meat cuts' by the European Union, they are not subjected to quotas (common nomenclature of MERCOSUR 'NCM', Resolution 13/2007). All this leads us to suggest that this 'differential' product may result in an interesting alternative to improve milk systems profitability.

\section{OBJECTIVE}

Assessing and comparing some productive parameters of artificial rearing systems of veal dairy calves, individually or in group, using a French protocol.

\section{MATERIALS AND METHODOLOGY}

The study was carried out from November 2014 to May 2015, in "cabaña Alicia" dairy farm (Lorentor S.A), located in 36 road, $\mathrm{km} \mathrm{78}$, in the district of Poblet, city of La Plata, province of Buenos Aires. The performed study has been a preliminary test, for the production system of veal calves is not currently practiced in our country.

The trial was based on a protocol resulting from experience. The experience was performed in three stages: start, development and termination. During these stages, the concentration and amount of dairy replacer varied, following the French protocol guidelines (Table $\mathrm{N}^{\circ} 1$ ).

Table $\mathrm{N}^{\circ}$ 1: Feeding protocol of Tullet et al., 1981

\begin{tabular}{|c|c|c|c|c|c|c|}
\hline \multicolumn{7}{|c|}{ Starting stage: Feeding program } \\
\hline \multirow{2}{*}{$\begin{array}{c}\text { Time } \\
\text { (weeks) }\end{array}$} & \multirow{2}{*}{$\begin{array}{l}\text { Concentration } \\
\text { (gr of replacer/ } \\
\mathrm{kg} \text { of water) }\end{array}$} & \multirow[t]{2}{*}{ DWG } & \multirow{2}{*}{$\begin{array}{c}\text { Body } \\
\text { Weight }\end{array}$} & \multicolumn{3}{|c|}{ Suggested amount } \\
\hline & & & & $\begin{array}{c}\text { Dairy } \\
\text { Replacer }\end{array}$ & $\begin{array}{l}\text { Weekly } \\
\text { Intake }\end{array}$ & Water \\
\hline 1 & 140 & 0 & 45 & 430 & 3010 & 3070 \\
\hline 2 & 161 & 286 & 45 & 555 & 3885 & 3445 \\
\hline 3 & 170 & 610 & 47 & 870 & 6090 & 5130 \\
\hline 4 & 194 & 1000 & 51 & 1220 & 8540 & 6280 \\
\hline \multicolumn{7}{|c|}{ Dairy replacer total intake amount 'Start stage' during the four weeks: $21,525 \mathrm{~kg}$. } \\
\hline
\end{tabular}




\begin{tabular}{|c|c|c|c|c|c|c|}
\hline \multicolumn{7}{|c|}{ 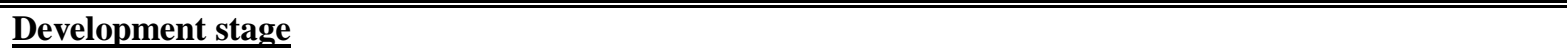 } \\
\hline \multirow{2}{*}{$\begin{array}{c}\text { Time } \\
\text { (weeks) }\end{array}$} & \multirow{2}{*}{$\begin{array}{l}\text { Concentration } \\
\text { (gr of replacer/ } \\
\mathrm{kg} \text { of water) }\end{array}$} & \multirow[t]{2}{*}{ DWG } & \multirow{2}{*}{$\begin{array}{c}\text { Body } \\
\text { Weight }\end{array}$} & \multicolumn{3}{|c|}{ Suggested amount } \\
\hline & & & & $\begin{array}{c}\text { Dairy } \\
\text { Replacer }\end{array}$ & $\begin{array}{l}\text { Weekly } \\
\text { Intake }\end{array}$ & Water \\
\hline 5 & 194 & 1200 & 58 & 1300 & 9100 & 6700 \\
\hline 6 & 208 & 1300 & 67 & 1730 & 12110 & 8300 \\
\hline 7 & 217 & 1300 & 76 & 1800 & 12600 & 8300 \\
\hline 8 & 223 & 1300 & 85 & 1895 & 13265 & 8503 \\
\hline \multicolumn{7}{|c|}{ Dairy replacer intake 'Development' during the four weeks: 47,075 Kg. } \\
\hline \multicolumn{7}{|c|}{ Termination stage } \\
\hline \multirow{2}{*}{$\begin{array}{c}\text { Time } \\
\text { (weeks) }\end{array}$} & \multirow{2}{*}{$\begin{array}{l}\text { Concentration } \\
\text { (gr of replacer/ } \\
\mathrm{kg} \text { of water) }\end{array}$} & \multirow[t]{2}{*}{ DWG } & \multirow{2}{*}{$\begin{array}{c}\text { Body } \\
\text { Weight }\end{array}$} & \multicolumn{3}{|c|}{ Suggested amount } \\
\hline & & & & $\begin{array}{c}\text { Dairy } \\
\text { Replacer }\end{array}$ & $\begin{array}{l}\text { Weekly } \\
\text { Intake }\end{array}$ & Water \\
\hline 9 & 223 & 1350 & 94 & 2005 & 14035 & 8995 \\
\hline 10 & 223 & 1350 & 103 & 2095 & 14665 & 9405 \\
\hline 11 & 228 & 1440 & 113 & 2300 & 16100 & 10100 \\
\hline 12 & 226 & 1440 & 123 & 2395 & 16765 & 10605 \\
\hline 13 & 225 & 1450 & 133 & 2495 & 17465 & 11105 \\
\hline 14 & 226 & 1450 & 143 & 2585 & 18095 & 11415 \\
\hline 15 & 226 & 1450 & 153 & 2670 & 18690 & 11830 \\
\hline 16 & 226 & 1470 & 163 & 2800 & 19600 & 12400 \\
\hline 17 & 226 & 1420 & 174 & 2800 & 19600 & 12400 \\
\hline 18 & 226 & 1400 & 184 & 2800 & 19600 & 12400 \\
\hline 19 & 226 & 1400 & 193 & 2800 & 19600 & 12400 \\
\hline 20 & 226 & 1400 & 202 & 2800 & 19600 & 12400 \\
\hline 21 & 226 & 1400 & 212 & 2900 & 20300 & 12600 \\
\hline 22 & 226 & 1400 & 222 & 2900 & 20300 & 12600 \\
\hline 23 & 230 & 1400 & 232 & 3100 & 21700 & 13000 \\
\hline 24 & 230 & 1400 & 241 & 3100 & 21700 & 13000 \\
\hline
\end{tabular}

12 Argentinean Holando non-castrated males between the 5 and 7 days of age were employed, with a body weight between 35 and $45 \mathrm{~kg}$ clinically healthy and calostrum fed. Calves immunity state was determined by means of a glutaraldehyde test. The aim of this test is to assess the amount of calostrum sucked from their mothers in the first 24 hours of life. The calostrum is the only source of defense that they are able to obtain, for they are born without any kind of antibodies (agammaglobulinemic) (Berra et al., 1997).

The rearing was performed in two group sheds with four animals each, and four individual sheds with sliding doors for good ventilation. As an additional ventilation system, two fans were installed, one on the floor and another one on the wall, only used in days of high temperature and low wind speed. Group sheds surface was $9.2 \mathrm{~m}^{2}$ and individual sheds surface was $4.2 \mathrm{~m}^{2}$, each with a trough. All sheds had to be clean, disinfected and dry.

In addition, sheds had wooden floors and sides to avoid animal contact with the ground, in order to improve their wellbeing and preserve their health. Straw or any other material used as bed was ruled out since, if ingested by the animals, it could alter the particular coloring of this kind of meat.

They were fed on an iron and fiber deficient dairy replacer-based liquid diet, designed to produce the peculiar pale color of this meat (Bertrand \& 
Martineau 1997). The food (Toullec et al., 1981) was supplied individually twice a day (at 6.00 AM and 18.00 PM respectively) at a temperature of $38^{\circ} \mathrm{C}-40^{\circ}$ $\mathrm{C}$. The amount of water was given willy-nilly during the months of highest temperature (December, January, and mid February) and then, only during the morning not to reduce the milk intake.

As regards the work staff, work routines were constant and performed regularly. The movements of the staff around the animals were discrete not to excite them. Also, a permanent control of health aspects was performed, especially on the most frequent pathologies taking place in this type of rearing: diarrhea and pneumonia. Appropriate treatments were applied in each case (Roy, 1972).

Measurements: productive parameters

-Daily body weight gain (DWG). Fortnightly weightings were made during the rearing period using an electronic scale. Once obtained the final weight of each calf, the initial weight was subtracted from that amount and such result was divided by the total amount of days of the study. It should be pointed out that fortnightly weightings were aimed at keeping a closer track of each calf.
-Beef yield: data were obtained from the slaughterhouse in charge of the slaughter.

-Meat color: an organoleptic assessment was made specifically on the characteristic color of the meat.

-Blood extraction was performed 100 days after the start of the rearing, and at its termination, in order to evaluate iron levels and control possible anemia occurrence.

\section{Statistic Analysis}

Data were evaluated statistically by means of variance analysis (ANOVA) and once the differences observed were proved to be significant, the means were compared by means of Tukey test.

This analysis was performed separately for the two study variables, body weight (BW) and daily body weight gain (BWG). The numbers resulting from the individual and group treatment were analyzed, together with the ones established by the French protocol.

\section{RESULTS AND DISCUSSION}

Observing the DWG calculated in the group and individual rearing, we find no significant statistic differences between the treatments (table $\mathrm{N}^{\circ} 2$ ).

Table $\mathrm{N}^{\circ}$ 2: statistical analysis of the DWG parameter expressed in gr/day in the group and individual rearing system.

\begin{tabular}{|c|c|}
\hline & DWG \\
\hline P value & 0.900000 \\
\hline Group rearing & $0.839 \mathbf{a}$ \\
\hline Individual rearing & $0.834 \mathbf{a}$ \\
\hline
\end{tabular}

Same letters do not differ significantly.

Content in Table $\mathrm{N}^{\circ} 3$ details initial, final and DWG data, within a period of 182 days. Also, a difference is established between individual rearing calves and group rearing calves.

Table $\mathrm{N}^{\circ}$ 3: daily body weight gain in the whole period.

\begin{tabular}{||c|c|c|c||}
\hline Sheds & $\begin{array}{c}\text { Initial } \\
\text { weights }\end{array}$ & Final weights & $\begin{array}{c}\text { DWG } \\
\text { kg/day }\end{array}$ \\
\hline Group & 53.50 & 196.10 & 0.78 \\
\hline Group & 50.00 & 188.40 & 0.76 \\
\hline Group & 46.50 & 201.75 & 0.85 \\
\hline Group & 39.50 & 185.25 & 0.80 \\
\hline Group & 38.50 & 104.40 & 0.36 \\
\hline Group & 41.00 & 174.80 & 0.74 \\
\hline Group & 48.50 & 165.40 & 0.64 \\
\hline Group & 42.00 & 163.30 & 0.67 \\
\hline Individual & 49.50 & 198.90 & 0.82 \\
\hline Individual & 62.00 & 208.40 & 0.80 \\
\hline Individual & 51.00 & 208.10 & 0.86 \\
\hline Individual & 43.00 & 153.90 & 0.61 \\
\hline DWG average & & $\mathbf{0 . 7 3}$ \\
\hline
\end{tabular}


The French protocol DWG average in the whole period is of $1.2 \mathrm{~kg}$ vs. 0.73 (Table $\mathrm{N}^{\circ} 3$ ) of the performed study, the latter being significantly lower, but still considered within reasonable levels.

These differences between DWG might be due to ambient conditions, for Europe has a higher level of control. Given that it can afford to make higher inversions in their systems, Europe is able to improve their animals' wellbeing. Moreover, originally, each country has adapted breeds to local conditions, orienting rearing to different objectives. In this sense, milk breeds of European countries may have been selected to be used for a double purpose. These countries have, therefore, a better aptitude to produce meat, unlike our country, where animals are mainly specialized for milk activity.

Veal calves are slaughtered between the 2 and 6 months of age with a bodyweight of between 100 and $250 \mathrm{~kg}$. This kind of animal must provide, together with a high beef yield (60\% approximately), a well formed beef that is sufficiently fat covered, and above all, a white meat. Contents in Table $\mathrm{N}^{\circ} 4$ detail the weights of each calf beef with their corresponding bodyweight. This information was provided by the slaughterhouse in charge of the slaughter (FRIGOLAR), authorized by ONCCA, for animals did not reach the allowed weight for slaughter. So, a special permit had to be requested to perform the activity for research purposes.

Table $\mathrm{N}^{\circ} 4$ : beef yield.

\begin{tabular}{|c|c|c|c|c||}
\hline Calf & $\begin{array}{c}\text { Beef 1 } \\
(\mathbf{K g})\end{array}$ & $\begin{array}{c}\text { Beef 2 } \\
(\mathbf{K g})\end{array}$ & $\begin{array}{c}\text { Calf } \\
\mathbf{B W} \\
(\mathbf{K g})\end{array}$ & $\begin{array}{c}\text { Yield } \\
\mathbf{( \% )}\end{array}$ \\
\hline 1 & 40 & 40 & 175.3 & 45.6 \\
\hline 2 & 58 & 57 & 188.4 & 60.5 \\
\hline 3 & 30 & 31 & 104.4 & 58.4 \\
\hline 4 & 50 & 50 & 172.4 & 58.2 \\
\hline 5 & 54 & 55 & 185.3 & 58.5 \\
\hline 6 & 63 & 62 & 208.1 & 59.9 \\
\hline 7 & 58 & 59 & 201.8 & 58.2 \\
\hline 8 & 58 & 57 & 196.1 & 58.6 \\
\hline 9 & 61 & 62 & 208.4 & 59.2 \\
\hline 10 & 59 & 59 & 199.0 & 59.1 \\
\hline 11 & 44 & 44 & 153.9 & 57.6 \\
\hline 12 & 52 & 51 & 178.8 & 57.6 \\
\hline Beef average yield & \multicolumn{5}{|l|}{} \\
\hline Average body weight & \multicolumn{5}{|l|}{} \\
\hline
\end{tabular}

It is also observed that BW average is $181 \mathrm{~kg}$ and the average beef yield is $57.6 \%$. The latter is very close to the optimum one of $60 \%$. Therefore, we may conclude that the result was good.

The characteristic color of the meat was observed and compared to that of a grazing animal. Results of the iron level analysis by means of blood extraction after 100 days of rearing were $8.2 \mathrm{gr} / \mathrm{dl}$ average of the 12 calves. At the termination of the cycle the values were on average $7.8 \mathrm{gr} / \mathrm{dl}$. It was observed that these values were considered within the expected parameters to avoid the occurrence of anemia without altering the meat's color.

\section{CONCLUSIONS}

Given the particular conditions where this study was performed, it is important to point out that a widely adopted rearing system in other countries, though never used before in Argentina, was reproduced successfully. It is also worth mentioning that since this system is a new activity, it might be improved in certain aspects. Improvements, therefore, will occur once it starts being adopted in more areas and by more people, so that more information is obtained about it.

The activity of animal protection societies against the distribution of this product is very strict in some European countries, so this should be something to take into account when considering undertaking this activity. Moreover, countries such as the United States overtly disagree with confinement rearing systems. Studies have demonstrated that this kind of system alters calves' behavior, causing psychological and physical damage (Reece \& Hotchkiss, 1987). 


\section{BIBLIOGRAPHY}

1. Bertrand G. \& Martineau C. 1997 a. intèrêt de I' apport d' un aliment solide sous forme de bouchons de paille à des veaux de boucherie élevés en 20 semaines. In: $2^{\circ}$ essai. Compte rendu N ${ }^{\circ} 97041$ de I' Institut de I' élevage.

2. Berra, G., Osacar, G. \& Cabral, C. 1997. Efecto de la incorporación diaria de FS 100 en sustitutos lácteos para terneros de tambo. Publ. Instituto de Patobiología CICVINTA-CASTELAR.

3. Bremner B. \& Dalgarno C. 1972. Iron metabolism in the veal calf.

4. Bisang R, Gutman G., Cesa V. 2003. La Trama de Lácteos en Argentina. Oficina de la CEPAL-ONU en Bs. As. Secretaría de Política Económica, Ministerio de Economía de la Nación.

5. Lumsden J.H., Mullen K., \& Rowe R. 1980. Hematology and biochemistry reference values for female Holstein cattle.
6. Nomeclador Común del MERCOSUR (NCM). Resolución 13/2007. Boletín Oficial de la Oficina Nacional de Control Comercial Agropecuario 4/1/2007

7. Hazard, S.1993. El calostro acidificado en la alimentación de terneros.Investigación y Progreso Agrícola Carillanca. 12(3):34-37.

8. Roy, J. H. 1972. El ternero. Nutrición y patologías. Editorial Acribia. Zaragoza. España. 197 p.

9. Reece W.O. \& Hotchkiss DK. 1987. Blood studies and performance among calves reared by different methods. J Dairy Sci 70:1601-1611.

10. Toullec R., Thivend P., Vermorel M., Gueguen L. 1981. Veau préruminant. In I.N.R.A., Alimentation des ruminants, 245-274. I.N.R.A. Publications, Versailles.

11. Vieira C., Cerdeño A. \& Mantecón A. 2004. Nutrición y Calidad de carne en terneros jóvenes. Mundo Ganadero $\mathrm{n}^{\circ}$ 165. 